\title{
EXTRACTIVE SPECTROPHOTOMETRIC DETERMINATION OF KETOCONAZOLE, CLOTRIMAZOLE AND FLUCONAZOLE BY ION-PAIR COMPLEX FORMATION WITH BROMOTHYMOL BLUE AND PICRIC ACID
}

\author{
*NINA ALIZADEH, ZAHRA REZAKHANI \\ *Department of Chemistry, University of Guilan, Namjoo Street, Rasht, P.B. 41335-1914, Iran
}

(Received: July 15, 2011 - Accepted: March 15, 2012)

\begin{abstract}
The reactions of picric acid and bromothymol blue with three important antifungal drugs containing an imidazole ring ketoconazole (KC) and clotrimazole (CT) and fluconazole (FC) have been studied for the development of simple, rapid, sensitive an extractive-spectrophotometric method for determining the concentration of these drugs. This method is based on the formation of yellow ion-pair complexes between the basic nitrogen of the drug and sulphonphthalein acid dyes, namely; bromothymol blue (BTB) in phosphate buffer of $\mathrm{pH}=3$ and picric acid (PA) in citrate buffer of $\mathrm{pH}=2.5$. The formed complexes were extracted with chloroform and measured at 410 and $415 \mathrm{~nm}$ for $\mathrm{KC}$, at 410 and $413 \mathrm{~nm}$ for CT and at 373 and $415 \mathrm{~nm}$ for FC using PA and BTB, respectively. The analytical parameters and their effects on the reported systems are investigated. Beer's law was obeyed in the range 1-60, 1-58 and 3-60 $\mu \mathrm{g} / \mathrm{mL}$ with PA and 3-55, 2-50 and 5-55 $\mu \mathrm{g} / \mathrm{mL}$ with BTB for CT, KC and FC, respectively. The composition of the ion pairs was found 1:1 by mole ratio and job $\notin \mathrm{s}$ method in all cases. The proposed methods have been applied successfully for the analysis of the studied drugs in pure forms and pharmaceutical formulations. The results are in good agreement with those obtained by official methods.
\end{abstract}

Keywords: Ketoconazole; Clotrimazole; Fluconazole ; Bromothymol blue; Picric acid; Spectrophotometry

\section{INTRODUCTION}

Ketoconazole (KC), cis-1-acetyl-4-[4-2-(2,4-dichlorophenyl)-2-(1Himidazole-1-yl methyl)-1,3-dioxolan-4-yl] methoxy piperazine(I), is widely used as a typical antifungal drug in the treatment of tinea infections [1]. KC is a potent inhibitor of cytochrome P-450-dependent steroid hydroxylation in the adrenals [2]. In addition, $\mathrm{KC}$ enhances microsomal epoxid hydrolase activity with some epoxide substrates [3].

Clotrimazole (CT), 1-[(2-chlorophenyl) diphenyl methyl]-1Himidazole(II), is an imidazole antifungal agent with similar action and activity to KC [4]. Most clinical studies indicate that systemic CT has little efficacy and considerable toxicity compared to other systemic imidazoles (miconazole and KC) [4]. Fluconazole(FC), [2-(2,4-difluorophenyl)-1,3-bis(1H-1,2, 4-triazol-1yl) propan-2-ol](III), is an orally active antifungal agent, which is used in the treatment of superficial and systemic candidiasis and cryptococcal infections in patients with the acquired immunodeficiency syndromes (AIDS). It acts by blocking the synthesis of ergosterol, an essential component of the fungal cell membrane. Thus, due to the vital importance of determination of these drugs in pharmaceutical preparations and biological fluids, several spectroscopic[5-12]. high per- formance liquid chromatographic[13-/17] and electrochemical [18123] methods for assay of $\mathrm{KC}$ and also, various methods such as derivative spectrophotometry [24-25],colorimetry [5-6-26-27], HPLC[28-/30], electrochemistry $[18]$ and differential scanning calorimetry (DSC) [31] have been reported for the determination of $\mathrm{CT}$ in the literature. The official method normally involves titration in non-aqueous solvent[32-33]. To the best of our knowledge, despite the important ionassociation complex formation and extractive spectrophotometric methods, there are no previous reports based on the reaction of $\mathrm{KC}$ and $\mathrm{CT}$ and fluconazole with picric acid (PA) and reaction this drugs with bromothymol blue (BTB) as ion pairing reagents.

In the present investigation, we report that the development of accurate, reproducible, less time consuming and adequately sensitive three extractivespectrophotometric methods based on the formation of ion-pair complexes between KC,CT and FC with anionic dye namely bromothymol blue (BTB) and picric acid (PA) in acidic buffer compared with other reported methods. The compositions of the complexes formed in proposed method have been established and after optimizing various analytical parameters, the obtained results were compared with those of official methods.

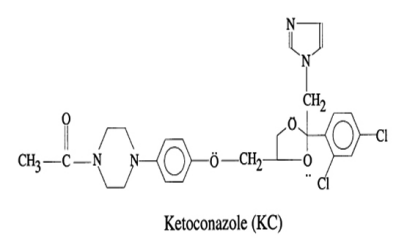

(I)

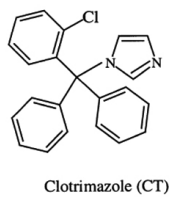

(II)

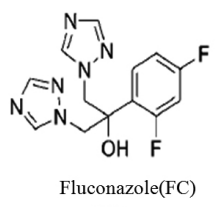

(III)

\section{EXPERIMENTAL}

Materials and Reagents

All chemicals used in this study were of highest purity available (Merck) and used without further purification. Doubly distilled deionized water was used throughout. The picric acid and bromothymol blue solution were freshly prepared and standardized Reagent grade KC and its $200 \mathrm{mg}$ tablet as well as $2 \%$ cream samples and reagent grade CT, $100 \mathrm{mg}$ vaginal tablet, $1 \%$ cream. were obtained from Behvazan Pharmaceutical Company (Rasht Iran) and standardized. capsules containing fluconazole containing $100 \mathrm{mg}$ and $200 \mathrm{mg}$ of the drug were obtained from Loghman Darou (Tehran Iran).

A working standard solution of $100 \mu \mathrm{g} / \mathrm{mL}$ ketoconazole or clotrimazole or fluconazole was prepared by dissolving $50 \mathrm{mg}$ of pure drug in $50 \mathrm{ml}$ of water containing few drops of hydrocholoric acid (about $0.04 \mathrm{M}$ for $\mathrm{KC}$ and $2 \mathrm{M}$ for $\mathrm{CT}$ and FC) followed by further diluting of $5 \mathrm{ml}$ of this solution to $50 \mathrm{ml}$.

\section{Apparatus}

A Shimadzu 2100 UV-Vis spectrophotometer with matched quartz cells of $1 \mathrm{~cm}$ path length, was used for all spectral measurements. The $\mathrm{pH}$ values were determined with a model 825 metrohm using a combined electrod.

\section{General procedure}

Aliquots $(1 \mathrm{~mL}, 100 \mu \mathrm{g} / \mathrm{mL})$ of standard $\mathrm{KC}, \mathrm{CT}$ and $\mathrm{FC}$ solution were transferred into a series of $25 \mathrm{~mL}$ separating funnels containing $3 \mathrm{~mL}$ of $0.1 \%$ w/v picric acid (or BTB) and $1 \mathrm{~mL}$ of citrate buffer of $\mathrm{pH} 2.5$ (or phosphate buffer of $\mathrm{pH} 3$ ) were added. Then, $5 \mathrm{ml}$ chloroform were added and the solution was shaken for $10 \mathrm{~min}$. The solution was allowed to stand for clear separation of the two phases. The formed complexes were extracted with chloroform and measured at 410 and $415 \mathrm{~nm}$ for KC, at 410 and $413 \mathrm{~nm}$ for CT and at 373 and $415 \mathrm{~nm}$ for FC using PA and BTB, respectively.

Blood serum sample

$0.25 \mathrm{~mL}$ of a $0.5 \mathrm{~mol} / \mathrm{L} \mathrm{FC}$ solution was added into $0.5 \mathrm{~mL}$ of a blood serum samole. The volume of the mixture was made to $5 \mathrm{~mL}$ in a calibrating volumetric flask and the general procedure of the proposed method was followed. 
Tablet sample solution

Five capsules of fluconazole were weighed accurately and their contents were mixed and powdered thoroughly and Ten tablets of each drug (CT and $\mathrm{KC}$ ) after determining the average weight were powdered. Powder of each drug equivalent to $25 \mathrm{mg}$ was accurately weighed and shaken with water containing a few drops of $\mathrm{HCl}(2 \mathrm{M}$ for $\mathrm{CT}, \mathrm{FC}$ and $0.04 \mathrm{M}$ for $\mathrm{KC}$ ) and the volume was filled up to $50 \mathrm{ml}$ in a volumetric flask, then, the recommended procedures for the determination of $\mathrm{KC}$ and $\mathrm{CT}$ were followed.The method of standard addition was used for the accurate determination of the ketoconazole and clotrimazole and fluconazole contents.

Cream sample solution

An accurately weighed portion of the cream or typical solution samples equivalent to $25 \mathrm{mg}$ of the drug was shaken and gently heated in ethanol until they were completely dissolved and then filtered. The resulting clear solution was diluted to $50 \mathrm{ml}$ with ethanol and recommended procedure was followed. The standard addition method was also employed for the accurate determination of the drug contents.

\section{RESULTS AND DISCUSSION}

Ion-pair complex extractive-spectrophotometry has been frequently used for the quantitative analysis of many pharmaceutical compounds [34]. In this study, we used PA and BTB as a suitable anionic dye, to form an intense yellow color ion-pair complex with $\mathrm{KC}$ and $\mathrm{CT}$ and $\mathrm{FC}$, in acidic $\mathrm{pH}$, which is soluble in chloroform and can be measured at at 410 and $415 \mathrm{~nm}$ for $\mathrm{KC}$, at 410 and $413 \mathrm{~nm}$ for CT and at 373 and $415 \mathrm{~nm}$ for FC using PA and BTB, respectively.

Absorption spectra of $2.5 \times 10^{-5}$ mol. $\mathrm{L}^{-1}$ of drugs (CT, KC and FC ) and PA ion-pair complexes in chloroform are shown in Fig. 1 with a maximum absorbance at $410 \mathrm{~nm}$ for CT, KC and $373 \mathrm{~nm}$ for FC with PA.The colorless blanks have practically negligible absorbance. Absorption spectra of $2.5 \times 10^{-5}$ mol. $\mathrm{L}^{-1}$ of drugs (CT, KC and $\mathrm{FC}$ ) and BTB ion pair complexes in chloroform are shown in Fig.2
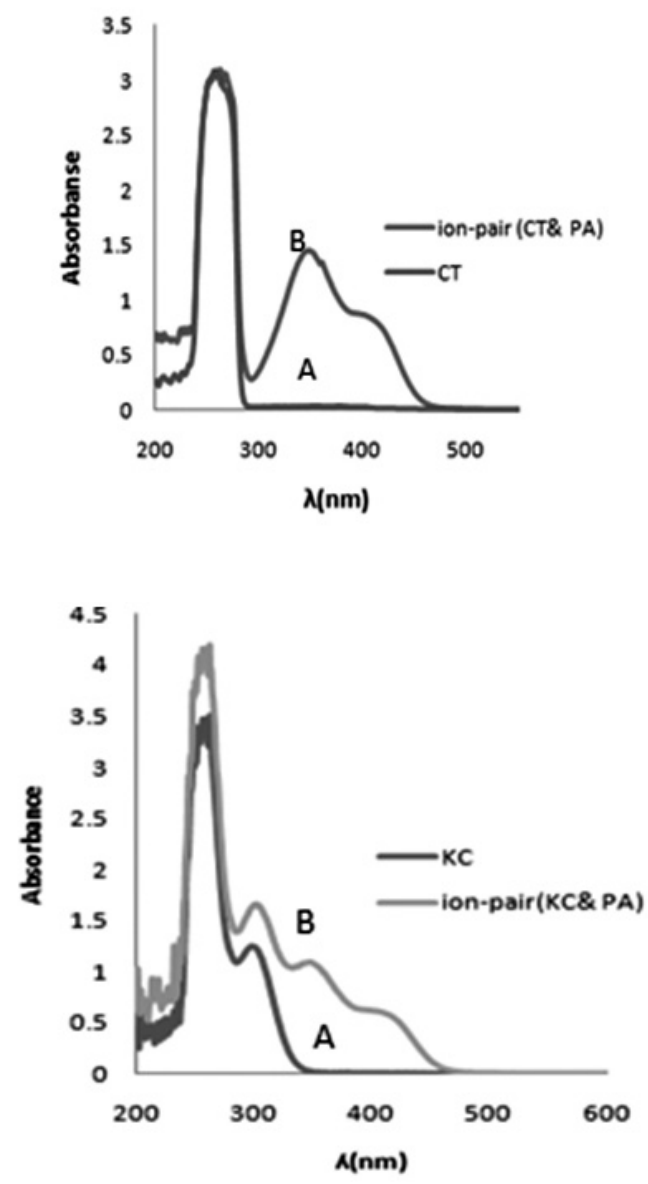

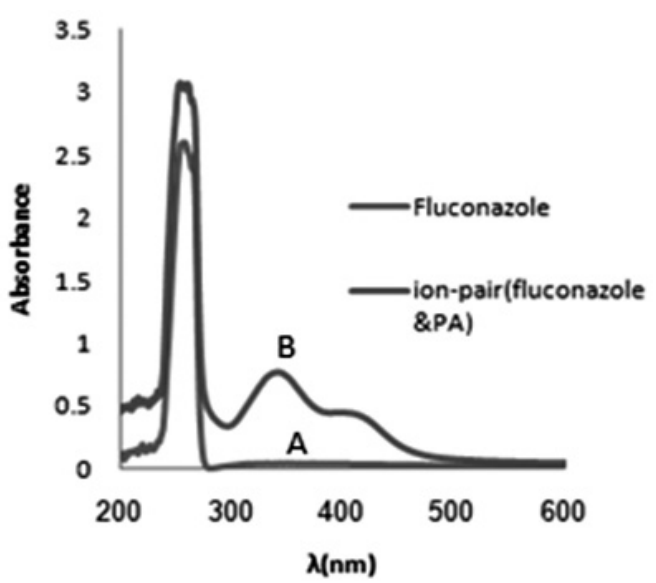

Fig. 1. electronic absorption spectra of drug (A) in chloroform and the extracted chloroform solution of drug in the presence of excess amount of picric acid solution (B)
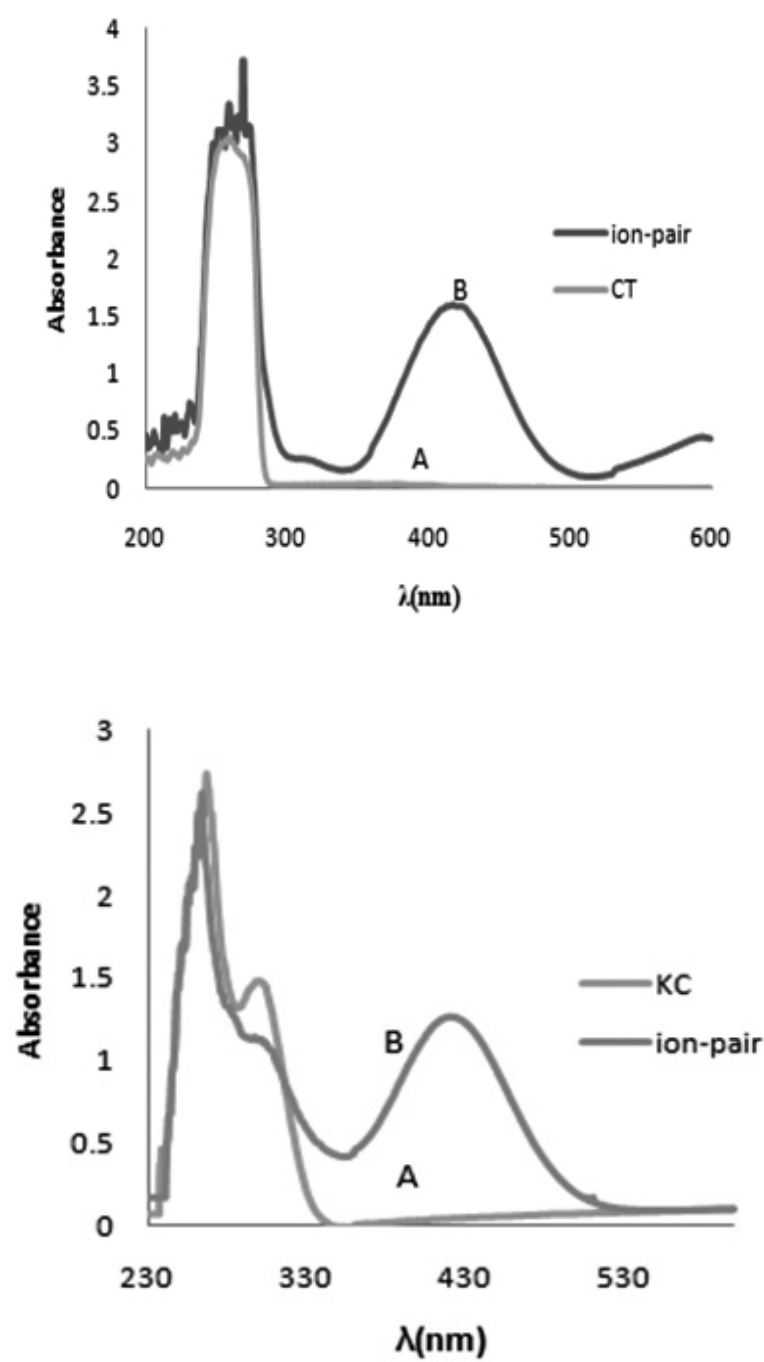


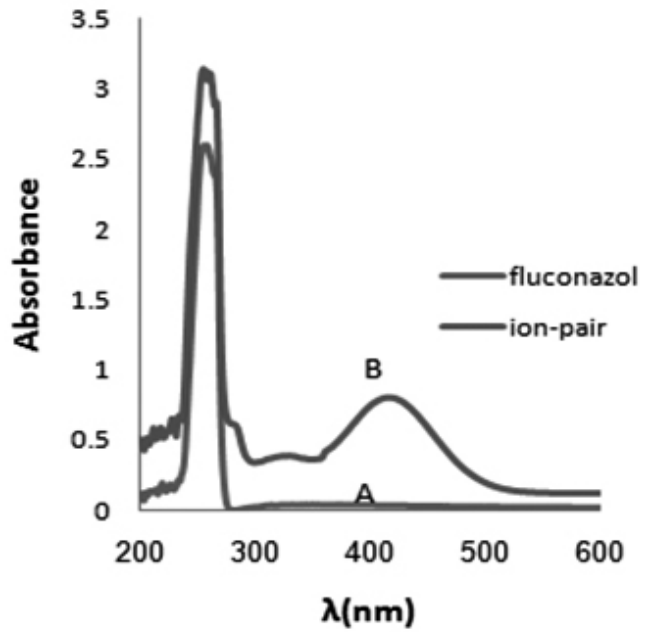

Fig. 2. electronic absorption spectra of drug (A) in chloroform and the extracted chloroform solution of drug in the presence of excess amount of Bromothymol blue solution (B)

Such pronounced spectral changes are presumably due to the occurrence of both charge-transfer and proton-transfer during the formation of the resulting molecular complex, as pointed out previously[36,38].

The absorbance vs. bromothymol blue or picric acid /drug mole ratio plot obtained at $410 \mathrm{~nm}$ for CT, KC and $373 \mathrm{~nm}$ for FC with PA (Fig.3) at $413 \mathrm{~nm}$ for $\mathrm{CT}, 415 \mathrm{~nm}$ for $\mathrm{KC}$ and $\mathrm{FC}$ with bromothymol blue is shown in Fig. 4. The resulting mole ratio plots show a distinct inflection point at a dye-to-drug mole ratio of about 1 , emphasizing the formation of a relatively strong 1:1 molecular complex in solution. The 1:1 stoichiometry was further supported by the method of continuous variations.

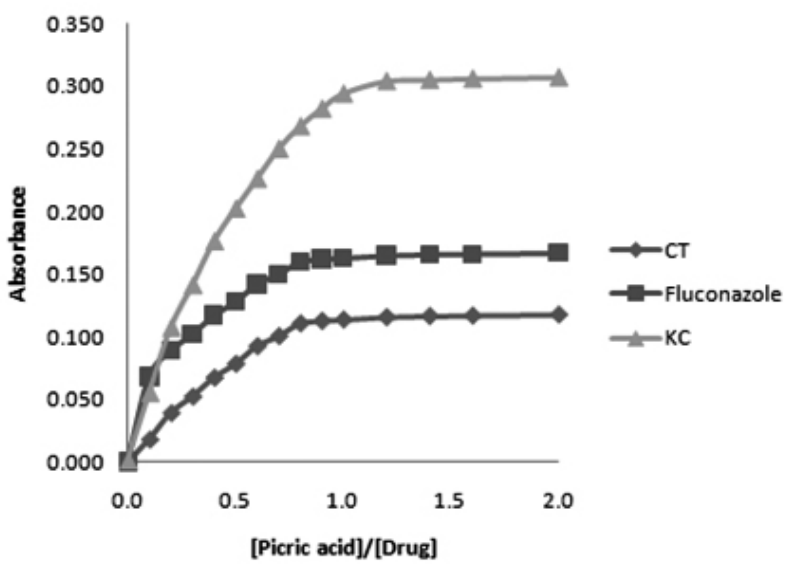

Fig. 3: Absorbance-mole ratio plots for KC-PA, CT-PA and FC-PA systems in chloroform at $25^{\circ} \mathrm{C}$.

\section{Optimization of conditions}

The optimum conditions for quantitative estimation of the associated ion-pair formed were established via a number of preliminary experiments. The effect of $\mathrm{pH}$ for the quantitative extraction of $\mathrm{KC}, \mathrm{CT}$ and $\mathrm{FC}$ with PA in chloroform was studied over the range 1-5, as it was established by using a proper citrate buffer. The resulting data at higher $\mathrm{pH}$ values show that the extent of ion-pair extraction decreases drastically, most probably due to the decreased amount of protonated form of drugs. At $\mathrm{pH}$ below 1-5, ion-pair extraction decrease. Thus, $\mathrm{pH} 2.5$ was chosen for further studies. The optimum $\mathrm{pH}$ value for the quantitative extraction of of $\mathrm{KC}, \mathrm{CT}$ and $\mathrm{FC}$ with bromothymol blue in chloroform was studied over the $\mathrm{pH}$ range of 2.5-7.0. According to the results a $\mathrm{pH}$ below 4.5 is recommended. At higher $\mathrm{pH}$ values, the fluconazole existed mainly in its neutral form ( $\mathrm{pKa}=2.03$ ) [37]. and the extent of ion pairing between anionic bromothymol blue and cationic fluconazole decreased, thus decreasing the color developed in chloroform phase. A pH value of 3.0 was used for further studies. .

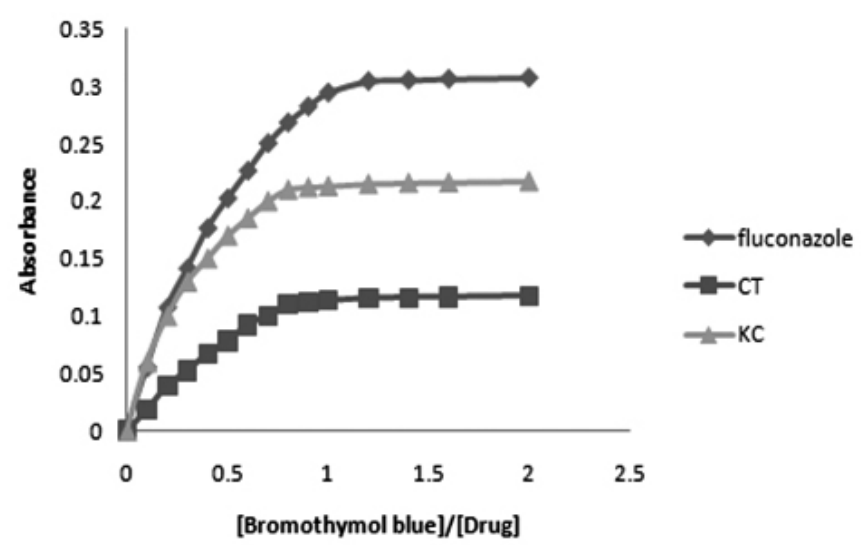

Fig.4: Absorbance-mole ratio plots for KC-BTB, CT-BTB, CT-BTB and FC-BTB systems inc.

In preliminary experiments, a number of immiscible organic solvents were examined in order to provide an applicable extraction procedure. Chloroform was found to be the most suitable extractant as it was observed that a single extraction was adequate to achieve a quantitative recovery of the complex. Despite the higher molar absorptivity of the complexes in methylene chloride, chloroform was preferred for its selective extraction of the drug-dye complex from the aqueous phase, mainly due to the lower volatility in comparison with methylene chloride. It is important to mentioned that the colored ion-pair complex in the chloroform phase is quite stable for several days. There was no appreciable change in the absorbance or colour of the product if the order of addition of the reactants is varied.

Moreover, the optimum volume of citrate buffer at $\mathrm{pH}=2.5$ and volume of phosphate buffer at $\mathrm{pH}=3$ was investigated and $1 \mathrm{~mL}$ of citrate and phosphate buffer was used for further studies.

The influence of the volume of picric acid $(0.1 \% \mathrm{w} / \mathrm{v})$ solution and bromothymol blue solution on the extraction of $\mathrm{CT}, \mathrm{KC}$ and $\mathrm{FC}$ was studied, as well. The absorbance of drug-picric acid complex and drug-bromothymol blue complexes in the organic phase increases with increasing amount of picric acid and bromothymol blue in the aqueous phase. Maximum extraction occurs when the volume of reagent added is $3 \mathrm{ml}$. A further excess of the reagent has no considerable effect on the fraction of the complex extracted.

The optimum volume of the organic phase and the number of extractions required were also studied. Maximum absorbance values were obtained by using $5 \mathrm{ml}$ of chloroform during a single stage extraction. In addition, the extraction of drug with dye under the conditions recommended was found to be rapid. A shaking time of 8-10 min is sufficient for the complete extraction of the resulting 1:1 ion pair complexes. Absorbances of the separated extracts were stable for more than $1 \mathrm{~h}$. The blanks did not absorb at $\lambda_{\max }$.

Linearity of calibration graphs

After the optimization of all the variables, the calibration graphs were constructed for the three drugs by plotting absorbance versus concentration in $\mu \mathrm{g} / \mathrm{mL}$. Beer's law was obeyed over the concentration range 1-58, 1-60 and $3-60 \mu \mathrm{g} / \mathrm{mL}$ for $\mathrm{KC}, \mathrm{CT}$ and $\mathrm{FC}$ by using picric acid indicator and 3-55, 2-50 and $5-55 \mu \mathrm{g} / \mathrm{mL}$ for KC, CT and FC by using bromothymol blue. Conformity with Beercs law was evident in the concentration ranges shown in Table 1. Regression analysis of the Beer $\phi$ s law plots at $\lambda_{\text {max }}$ reveal a good correlation, $\left(\mathrm{R}^{2}=0.981-0.995\right)$. Regression equations, intercepts, slopes and correlation coefficients for the calibration data are presented in Table 1. The following equations correspond to the linear ranges for $\mathrm{KC}$ and $\mathrm{CT}$ and $\mathrm{FC}$ with picric acid:

$\mathrm{KC}: \mathrm{A}=0.008 \mathrm{C}(\mu \mathrm{g} / \mathrm{mL})+0.002, \mathrm{R}^{2}=0.991, \mathrm{n}=6 \mathrm{CT}: \mathrm{A}=0.001 \mathrm{C}(\mu \mathrm{g} /$ $\mathrm{mL})-0.007, \mathrm{R}^{2}=0.992, \mathrm{n}=6$

$\mathrm{FC}: \mathrm{A}=0.0144 \mathrm{C}(\mu \mathrm{g} / \mathrm{mL})+0.245, \mathrm{R}^{2}=0.981, \mathrm{n}=6$

The following equations correspond to the linear ranges for $\mathrm{KC}$ and $\mathrm{CT}$ and $\mathrm{FC}$ with bromothymol blue:

$\mathrm{KC}: \mathrm{A}=0.007 \mathrm{C}(\mu \mathrm{g} / \mathrm{mL})-0.004, \mathrm{R}^{2}=0.984, \mathrm{n}=6 \mathrm{CT}: \mathrm{A}=0.002 \mathrm{C}(\mu \mathrm{g} /$ $\mathrm{mL})-0.006, \mathrm{R}^{2}=0.995, \mathrm{n}=6$

$\mathrm{FC}: \mathrm{A}=0.015 \mathrm{C}(\mu \mathrm{g} / \mathrm{mL})+0.218, \mathrm{R}^{2}=0.993, \mathrm{n}=6$

$\mathrm{A}=$ absorbance; $\mathrm{C}=$ drug concentration. The detection limit, calculated following the expression $\mathrm{a}+3 \mathrm{~S}_{\mathrm{xy}}$ [35], where $\mathrm{a}=$ /intercept and $\mathrm{S}_{\mathrm{xy}}=$ /error standard deviation, was $1.32,0.53$ and $4.1 \mu \mathrm{g} / \mathrm{mL}$ for $\mathrm{KC}, \mathrm{CT}$ and $\mathrm{FC}$ with 
picric acid and 1.02, 0.41 and $3.6 \mu \mathrm{g} / \mathrm{mL}$ for $\mathrm{KC}, \mathrm{CT}$ and $\mathrm{FC}$ with bromothymol blue respectively.

Quantification, accuracy and precision

The validity of the proposed procedure for the determination of the studied drugs in their pure state and in their pharmaceutical formulations, was tested by analyzing these products using the proposed procedure and the official method [33]. The results obtained for pure drugs (Table 1) were reproducible with low relative standard deviations and the mean recoveries were comparable to these obtained using the official method (Table 2) for each of the studied drugs. The results of analysis obtained for pharmaceutical forms obtained by the proposed and the official methods are in good agreement.

Table 1. Analytical data in the determination of the studied drugs using the proposed methods $(\mathrm{n}=6)$.

\begin{tabular}{|c|c|c|c|c|c|c|}
\hline \multirow[t]{2}{*}{ Parameters } & \multicolumn{2}{|c|}{ Ketoconazole } & \multicolumn{2}{|c|}{ Clotrimazole } & \multicolumn{2}{|c|}{ Fluconazole } \\
\hline & PA & BTB & PA & BTB & PA & BTB \\
\hline $\begin{array}{l}\text { Wavelengths } \lambda_{\text {max }}(\mathrm{nm}) \\
\text { Linear range }(\mu \mathrm{g} / \mathrm{mL})\end{array}$ & $\begin{array}{l}410 \\
1-60\end{array}$ & $\begin{array}{r}415 \\
3-55 \\
\end{array}$ & $\begin{array}{r}410 \\
1-58 \\
\end{array}$ & $\begin{array}{r}413 \\
2-50\end{array}$ & $\begin{array}{r}373 \\
3-60 \\
\end{array}$ & $\begin{array}{l}415 \\
5-55\end{array}$ \\
\hline $\begin{array}{c}\text { Molar absorptivity } \\
\left(\mathrm{L} \quad\left(\mathrm{L} \cdot \mathrm{mol}^{-1} \mathrm{~cm}^{-1} \times 10^{3}\right)\right. \\
\text { correlation coefficient }\left(\mathrm{R}^{2}\right)\end{array}$ & $\begin{array}{l}3.4 \\
0.991\end{array}$ & $\begin{array}{r}4.8 \\
0.994\end{array}$ & $\begin{array}{c}9.3 \\
0992\end{array}$ & $\begin{array}{c}9.9 \\
0.995\end{array}$ & $\begin{array}{c}3.2 \\
0.981\end{array}$ & $\begin{array}{c}4.8 \\
0.993\end{array}$ \\
\hline $\begin{array}{c}\text { Detection limit }(\mu \mathrm{g} / \mathrm{mL}) \\
\text { Quantitation } \\
\operatorname{limit}(\mu \mathrm{g} / \mathrm{mL})\end{array}$ & $\begin{array}{l}0.53 \\
1.76\end{array}$ & $\begin{array}{l}0.41 \\
1.37\end{array}$ & $\begin{array}{l}1.32 \\
4.40\end{array}$ & $\begin{array}{l}1.02 \\
3.40\end{array}$ & $\begin{array}{c}4.1 \\
13.66\end{array}$ & $\begin{array}{c}3.6 \\
12.00\end{array}$ \\
\hline $\begin{array}{c}\text { R.S.D\%*(Relative } \\
\text { standard deviations) }\end{array}$ & 1.72 & 1.85 & 1.5 & 1.8 & 1.71 & 1.91 \\
\hline RE\%(Relative error) & 1.76 & 1.87 & 1.56 & 2.02 & 1.77 & 2.05 \\
\hline
\end{tabular}

* confidence limit (95\%), 6 replicate measurements.

Effects of interference

The effects of common excipients that often accompany the studied drugs in pharmaceutical dosage were tested for possible interference in the assay. An attractive feature of the procedure is its relative freedom from interference by the usual tablet diluents and excipients such as talc, sucrose, starch, gelatin, and magnesium stearate. Amounts far in excess of their normal occurrences in dosage forms were added, and no effects due to these excipients were noted in the experimental procedure. Moreover, no interference due to yhe degradation products of the studied drugs was observed.

Application to dosage forms

In order to establish the validity of the proposed analytical methods, the assay of $\mathrm{KC}, \mathrm{CT}$ and $\mathrm{FC}$ in their formulations were carried out on proprietary drugs. The same samples were analyzed by the official non-aqueous potentiometric method (Table 2) $[32,33]$. The recovery experiments shown in Table 2 indicated a good agreement between the $\mathrm{KC}$ and $\mathrm{CT}$ and $\mathrm{FC}$ contents determined by the proposed and official methods as well as the declared amount of drug in the preparations used. This is indicative of non-interference of the other ingredients and the excipients, which are present in the formulations.

Table 2. Results of assay of studied drugs in pharmaceutical formulations by the proposed and official methods

\begin{tabular}{|c|c|c|c|}
\hline Formulation & Labeled & $\begin{array}{c}\text { Official } \\
\text { method }(\mathrm{n}=4) \\
(\% \text { Recovery } \\
\pm \text { S.D. })\end{array}$ & $\begin{array}{c}\text { Proposed } \\
\text { method }(\mathrm{n}=6) \\
(\% \text { Recovery } \\
\pm \text { S.D. })\end{array}$ \\
\hline Capsule (FC) & $200(\mathrm{mg}$ per capsule) & - & $99.89 \pm 0.03$ \\
\hline Capsule (FC) & $100(\mathrm{mg}$ per capsule) & - & $99.71 \pm 0.05$ \\
\hline Tablet (KC) & 200 (mg per tablet) & $101.0 \pm 0.6$ & $99.98 \pm 0.40$ \\
\hline Cream (KC) & 2 (wt.\% drug) & $99.5 \pm 1.0$ & $98.10 \pm 0.61$ \\
\hline Tablet (CT) & 100 (mg per tablet) & $102.0 \pm 0.9$ & $101.82 \pm 0.86$ \\
\hline Cream (CT) & 1 (wt.\% drug) & $102.8 \pm 1.1$ & $100.54 \pm 0.36$ \\
\hline
\end{tabular}

Recovery of fluconazole from blood serum

In order to investigate the applicability of the proposed method to the determination of the fluconazole in biological fluids, it was applied to the recovery of the fluconazole from a blood serum sample. The recovery of the fluconazole using the proposed method and the standard addition technique[12] was found to be $84 \% \pm 4$.

\section{ACKNOWLEDGMENTS}

Financial support from the Research Affairs of Guilan University is acknowledged. The authors are grateful to the Behvazan Pharmaceutical Company, ( Rasht industrial city, Iran) for the donation of pure drugs and its preparations.

\section{REFERENCES}

1. Delgado J.N, Remers W.A., Wilson and Fisvold's Text book of Organic Medical and Pharmaceutical Chemistry, Wiley, New York, (1991).

2. Kowal J, The effect of ketoconazole on steroidogenesis in cultured mouse adrenal cortex tumor cells, Endocrinology (1983) 112: 1541-/1543.

3. James M.O, Sloan K.B, Structure features of imidazole derivatives that enhance styrene oxide hydrolase activity in rat hepatic microsomes, $J$. Med. Chem. (1985) 28: 1120-1124.

4. American Medical Association, American Medical Association (AMA) Drug Evaluations, 5th ed., American Medical Association, (1983) 1349$/ 1350$.

5. El-Shabouri S.R, Emara K.M, P.Y, Khashaba A.M, Mohamed, Chargetransfer complexation for spectrophotometric assay of certain imidazole antifungal drugs, Anal. Lett. (1998)31: 1367-1385.

6. Kelani K, Bebawy L.I, Abdel-Fattah L. and Ahmad, A.S. Spectrophotometric determination of some $\mathrm{n}$-donating drugs using DDQ, Anal. Lett. (1997) 30: 1843-/1860.

7. Sane R.T, Tendolkar R.V, Gangal D.P, Ladage K.D and Kothurkar R.M. An extractive colorimetric method for the determination of ketoconazole for pharmaceutical preparations, Indian J. Pharm. Sci. 50 (1988) 50:3471348 .

8. Rao G.R, Rao P.J, Murty S.S.N. Spectrophotometric determination of ketoconazole, Indian Drugs (1988) 26: 1119-/1120.

9. Abounassif M.A, El-Shazly B.M. D-differential potentiometric and proton NMR spectrometric determination of ketoconazole and its formulations, Anal. Lett. (1989) 22: 2233-/2247. 
10. Zarapkar S.S and Halkar U.P.M. A simple extractive colorimetric determination of ketoconazole from pharmaceutical preparations, Indian Drugs (1991) 28: 265-269.

11. Kedor-Hackmann E.R.M, Nery M.M.F and Sanntoro M.I.R.M. Determination of ketoconazole in pharmaceutical preparations by ultraviolet spectrometry and high performance liquid chromatography, Anal. Lett. (1994) 27: 363-376.

12. Sadeghi S and Shamsipur M. A new extractive-spectrophotometric method for the determination of ketoconazole from pharmaceutical preparations, Anal. Lett. (1998) 31: 2691- 2705.

13. Badcock N.R. Micro-determination of ketoconazole in plasma, $J$. Chromatogr. (1984) 306: 436-440.

14. Riley C.M and James M.O. Determination of ketoconazole in the plasma, liver, lung and adrenal of the rat by highperformance liquid chromatography, J. Chromatogr. (1986) 337: 278-/294.

15. Al-Meshal M.A. Determination of ketoconazole in plasma and dosage forms by high-performance liquid chromatography and a microbiological method, Anal. Lett. (1989) 22: 2249-/2263. Farhadi K and Maleki R. J. Pharm. Biomed. Anal. (2002) 30: 1023-/1033

16. Di Pietria A.M, Cavrini V, Andriano V and Gatti R., HPLC analysis of imidazole antimycotic drugs in pharmaceutical preparations, J. Pharm. Biomed. Anal. (1992) 10: 873-/879.

17. Alhaique F, Anchisi C, Fadda A.M, Maccioni A.M. and Travagli V. Miconazole, ketoconazole and liposonal preparations: a reversed-phase HPLC determination, Acta Technol. Legis. Med. (1993) 4: 169-/175.

18. Fijalek Z, Chodkowski J and Waraowna M. Polarographic investigations of imidazole-derived drugs. I. Clotrimazole and ketoconazole, Acta Pol. Pharm. (1992) 49: 1-/5.

19. Sarna K and Fijalek Z. Polarographic and voltammetric study of ketoconazole on mercury and solid electrodes, Acta Pol. Pharm. (1996) 53: 163-/166.

20. Shamsipur M and Jalali F. Preparation of ketoconazole ionselective electrode and its application to pharmaceutical analysis, Anal. Sci. (2000) 16: 549-/552.

21. Shamsipur $\mathrm{M}$ and Farhadi Kh. Electrochemical behavior and determination of ketoconazole from pharmaceutical preparations, Electroanalysis (2000) 12: 429-/433.

22. Shamsipur $M$ and Farhadi Kh. Adsorptive stripping voltammetric determination of ketoconazole in pharmaceutical preparations and urine using carbon paste electrodes, Analyst (2000) 125: 1639-/1643.

23. Shamsipur $\mathrm{M}$ and Farhadi Kh. Electrooxidation of ketoconazole in acetonitrile and its determination in pharmaceutical preparations, Chem. Anal. (Warsaw) (2001) 46: 387-395.

24. Bedair M.M., Korany M.A, Elsayed, M.A.E and Fahmy O.T. Derivative spectrophotometric determination of clotrimazole in single formulation and in combination with other drugs, J. Assoc. Off. Anal. Chem. (1989) 72: $432-435$.

25. Prasad C.V.N, Parihar C, Sunil K and Parimoo P. Simultaneous determination of tinidazole-/clotrimazole and tinidazole-/norfloxacin in combined tablet preparations by derivative spectroscopy, Pharm. Sci. (1997) 3: 337-/341.

26. Shingbal D. $M$ and Kudchakar H.S. Colorimetric method for the estimation of clotrimazole, Indian Drugs (1987) 24: 408-/410.

27. Abdelmageed O. H and Khashaba P.Y. Spectrophotometric determination of clotrimazole in bulk drug and dosage forms, Talanta (1993) 40: 1289 /1294.

28. Hoogerheide J.G, Strusiak S.H, Taddei C.R, Townley E.R and Wyka B.E. High-performance liquid chromatographic determination of CT in pharmaceutical formulations, J. Assoc. Off. Anal. Chem. (1981) 64: 846849.

29. Valenta C, Lexer A and Spiegl P. Analysis of clotrimazole in ointments by high-performance liquid chromatography, Pharmazie (1992) 47: 641/642.

30. Tendulkar N.M, Desai B.S and Shinde V.M. Simultaneous determination of tinidazole and clotrimazole from tablets by RP-HPLC, Indian Drugs (1994) 31: 551-/553.

31. (a) Yang L. Test for purity of pharmaceuticals by differential scanning colorimetry (DSC), Yaowu Fenxi Zazhi (1988) 8: 345-/347;(b) Yang L. Test for purity of pharmaceuticals by differential scanning colorimetry (DSC), Chem. Abstr. n110, 141625j.

32. United States Pharmacopeia, 16th edition, Easton, PA, (1985) 580.

33. British Pharmacopia, HM Stationary Office, London, (1993) 170
34. Pesez M and Bartos J. Colorimetric and Fluorimetric Analysis of Organic Compounds and Drugs, Marcel Dekker, New York, (1974).

35. Miller J.C and Miller J.N. Statistics for Analytical Chemistry, 2nd ed., Ellis Harwood, Chichester, UK, (1988) 103.

36. Bennett J. E. In The Pharmacological Basis of Therapeutics, Eds.: Goodman-gilman, A.; Rall, T. W.; Nies, A. S.;Taylor, P., McGraw-Hill, Singapore, (1992) 1172.

37. Rippon J. W and Fromtling R. A. Cutaceous Antifungal Agents, Marcel Dekker Inc., (1993) 185.

38. Issa K.M, Abu-El-Wafa, S. Gaber M. and Mohamed E. H. A. Acta. Chim. Hung., (1985) 118: 179 